\title{
Anurans of the Caparaó National Park and surroundings, southeast Brazil
}

\author{
Camila Zornosa-Torres $^{1,2, *}$, Guilherme Augusto-Alves ${ }^{1,2}{ }^{\oplus}$, Mariana L. Lyra ${ }^{\circledR}{ }^{\circledR}$, José Cassimiro da Silva Júnior ${ }^{4}$, \\ Paulo C.A. Garcia ${ }^{5}{ }^{\circledR}$, Felipe Leite $^{6}$, Vanessa Verdade ${ }^{7}$, Miguel T. Rodrigues $^{4}$, João Luiz Gasparini ${ }^{8}$, Célio F.B. Haddad \\ \& Luís Felipe Toledo \\ ${ }^{1}$ Universidade Estadual de Campinas (UNICAMP), Instituto de Biologia, Departamento de Biologia Animal, \\ Laboratório de História Natural de Anfibios Brasileiros (LaHNAB), Cidade Universitária Zeferino Vaz, Rua \\ Monteiro Lobato, 255, 13083-862, Campinas, SP, Brasil. \\ ${ }^{2}$ Universidade Estadual de Campinas (UNICAMP), Instituto de Biologia, Programa de Pós-Graduação em \\ Ecologia, Rua Monteiro Lobato, Cidade Universitária Zeferino Vaz, 255, 13083-862, Campinas, SP, Brasil. \\ ${ }^{3}$ Universidade Estadual Paulista (UNESP), Instituto de Biociências, Departamento de Biodiversidade e Centro \\ de Aquicultura (CAUNESP), Av. 24-A, 1515, Bela Vista, 13506-900, Rio Claro, SP, Brasil. \\ ${ }^{4}$ Universidade de São Paulo (USP), Instituto de Biociências, Rua do Matão, Departamento de Zoologia, \\ Travessa 14, 101, Cidade Universitária, 05508-090, São Paulo, SP, Brasil. \\ ${ }^{5}$ Universidade Federal de Minas Gerais (UFMG), Instituto de Ciências Biológicas, Departamento de Zoologia, \\ Av. Antônio Carlos, 6627, 31270-901, Belo Horizonte, MG, Brasil. \\ ${ }^{6}$ Universidade Federal de Viçosa (UFV), Instituto de Ciências Biológicas, Rodovia LMG 818, Km 6, 35690-000, \\ Florestal, MG, Brasil. \\ ${ }^{7}$ Universidade Federal do ABC (UFABC), Centro de Ciências Naturais e Humanas, Av. dos Estados, 5001, \\ Bangú, 09210-580, Santo André, SP, Brasil. \\ ${ }^{8}$ Universidade Federal do Rio de Janeiro (UFRJ), Instituto de Biodiversidade e Sustentabilidade (NUPEM), \\ Programa de Pós-Graduação em Ciências Ambientais e Conservação (PPG-CiAC), Caixa postal 119331, \\ 27910-970, Macaé, RJ, Brasil. \\ *Corresponding author: Camila Zornosa-Torres,e-mail: camilitazt@gmail.com
}

ZORNOSA-TORRES, C., AUGUSTO-ALVES, G., LYRA, M.L., SILVA JÚNIOR, J.C., GARCIA, P.C.A., LEITE, F., VERDADE, V., RODRIGUES, M.T., GASPARINI, J.L., HADDAD, C.F.B., TOLEDO, L.F. Anurans of the Caparaó National Park and surroundings, southeast Brazil. Biota Neotropica 20(3): e20190882. https://doi.org/10.1590/1676-0611-BN-2019-0882.

\begin{abstract}
The Atlantic Forest (AF) is one of the biodiversity hotspots of the world, and the most fragmented biome of Brazil. This biome includes different phytophysiognomies, as riparian, slope, cloudy forests, and grasslands. Such complexity, allied to huge latitudinal and high elevational range, provides diverse habitats and conditions for amphibian speciation. As a result, there are over 600 amphibian species known to occur in the AF. Within this biome the Caparaó National Park (CNP) is relevant, as it includes the highest peak of the biome, the Pico da Bandeira at almost 3,000 $\mathrm{m}$ above sea level, as well as different phytophysiognomies as rocky fields and humid forests. In spite of that, its amphibian fauna is still poorly described. We inventoried amphibians at the CNP and surrounding areas from 2016 to 2018 and recorded 47 anuran species, of which two are locally endemic and at least six have not been described yet. Additionally, we compiled data from previous surveys (2004 to 2008) and secondary data from scientific collections. All together, we registered a total of 61 anuran species from 12 families for the CNP and surroundings, placing this area among the 10 amphibian richest sites in the AF. Some of these species are represented by only one or two collected specimens and have not been registered in the CNP since the 1980's, such as Thoropa lutzi and Hylodes vanzolinii. These species could be examples of population declines or even past local extinctions, highlighting the need of further sampling efforts in that highly biodiverse site. Keywords: Amphibia; frogs; toads; Atlantic Forest; species composition; species lists.
\end{abstract}




\title{
Anuros do Parque Nacional do Caparaó e arredores, sudeste brasileiro
}

\begin{abstract}
Resumo: A Mata Atlântica (MA) é considerada um dos hotspots de biodiversidade do mundo, sendo o bioma mais degradado no Brasil. Este bioma compreende muitas fitofisionomias, como floresta ombrófila, semidecidual, e campos de altitude. Esta complexidade, aliada à enorme variação latitudinal e altitudinal, disponibiliza habitats e condições diversas à especiação dos anfíbios. Como resultado, atualmente são conhecidas mais de 600 espécies de anfíbios que ocorrem na MA. Dentro deste bioma o Parque Nacional do Caparaó (PNC) é relevante, pois inclui o ponto mais alto da Mata Atlântica, o Pico da Bandeira com cerca de $3000 \mathrm{~m}$ de elevação, assim como diferentes fitofisionomias, como campos rupestres e florestas úmidas. Apesar disso, sua fauna de anfíbios é ainda pobremente descrita. Realizamos inventários de anfíbios no PNC e entorno de 2016 a 2018 e registramos 47 espécies de anuros, das quais duas são endêmicas e pelo menos seis ainda não foram descritas. Adicionalmente, compilamos dados de coletas anteriores (2004 a 2008) e dados secundários de coleções científicas. Ao juntar todos os dados registramos um total de 61 espécies de anuros de 12 famílias para o PNC e arredores, colocando esta área entre as 10 áreas mais ricas em anfíbios da MA. Algumas destas espécies estão representadas apenas por um ou dois exemplares em coleções e não foram registradas no PNC desde a década de 1980, como Thoropa lutzi e Hylodes vanzolinii. Estas espécies podem ser exemplos de declínios populacionais ou mesmo de extinções locais, destacando a necessidade de maiores esforços amostrais neste local altamente biodiverso.
\end{abstract}

Palavras-chave: Amphibia; composição de espécies; lista de espécies; Mata Atlântica; rãs; sapos.

\section{Introduction}

The Atlantic Forest (AF) is one of the most degraded biomes of Brazil, with less than $16 \%$ of its original extension, due to severe anthropic pressure over the past couple centuries (Ribeiro et al. 2011, Rossa-Feres et al. 2018). This biome is characterized by having different phytophysiognomies as evergreen, deciduous and semi-deciduous forest, mangroves, swamps, dunes and high-altitude grasslands (Ribeiro et al. 2011), high latitudinal variation (almost from the equator line, down to subtropical regions), and high topographic complexity (Morellato \& Haddad 2000, Toledo et al. 2014). Due to the high number of endemic species and the huge habitat loss it has been considered one of the 35 biodiversity hotspots of the world (Mittermeier et al. 2011), and therefore, conservation of this biome is a priority.

The AF amphibians are also diverse and represented by more than 600 species, of which about $75 \%$ are endemic, and several species yet to describe (Haddad et al. 2013, Rossa-Feres et al. 2018). In the AF, humidity and vegetation cover are determinants of amphibian species diversity, which are related to altitudinal variation (Vasconcelos et al. 2014). Some of the AF mountains are traditional centers of endemism, due to their elevation, climatic variation and biogeographic history (Guarnizo \& Cannatella 2013, Vasconcelos et al. 2014).

The mountain region of the Caparaó National Park (CNP) in the border of the states of Minas Gerais and Espírito Santo, southeastern Brazil, includes the highest peak of the Atlantic Forest, reaching almost 3,000 $\mathrm{m}$ above sea level. The area is covered by different phytophysiognomies (e.g., riparian, slope and cloudy forests; grasslands), and houses a diverse amphibian biota (Ferreira et al. 2015), including micro endemic species, as Cycloramphus bandeirensis (Heyer 1983). In spite of the potential relevance of the area for amphibian diversity, the single amphibian species list available was based on a 20 days survey and reported only 21 anuran species (Ferreira et al. 2015).

Here, we present an improved list of the anuran species of the Caparaó National Park and surroundings based on a period of almost seven years of fieldwork in the region and accessing information from scientific collections, including sound recordings and vouchered specimens.

\section{Material and Methods}

\section{Study site}

We searched for amphibians in the Caparaó National Park (CNP) and surroundings (Figure 1A). The Caparaó National Park is located between the states of Minas Gerais and Espírito Santo, southeastern Brazil, and belongs to the massif of Caparaó, which is part of the north region of the Serra da Mantiqueira (a mountain range) in the Atlantic Forest. Seasons in the CNP region are divided in a rainy summer (from November to March) and a wet winter (from April to October). The CNP has a huge elevational variation, from 859 to $2,892 \mathrm{~m}$ above sea level (a.s.l.), and the predominant phytophysiognomies are ombrophilous rainforests and high-altitude grasslands (above 1,900 m a.s.l.) (Machado et al. 2016).

\section{Field and scientific collections samplings}

We conducted field surveys from 2016 to 2018 in the Caparaó National Park and surroundings. We sampled 62 sample sites/units (SUs) (Figure 1A, Table S1), mainly during rainy season (see above), totaling 63 sampling days, as follows: 29 January to 03 February 2016, 27 July to 01 August 2016, 19-25 October 2016, 02-12 December 2016, 06-15 January 2017, 05-12 October 2017, 06-12 December 2017, 16-25 January 2018 and 22 November to 04 December 2018.

During these surveys we actively and acoustically searched for amphibians in possible breeding sites (Figure 2) inside and outside the park, both in its East and West slopes. These slopes were delimited by the downstream direction of the rivers. We also search in specific localities where rare species were registered in the past. Adult anurans were collected, anesthetized, and killed with lidocaine 5\%, fixed in $10 \%$ formalin, and stored in $70 \%$ ethanol. Tadpoles were fixed and stored in $7 \%$ formalin. For all individuals we collected muscle tissue samples before fixing the specimens and stored at $100 \%$ ethanol. Voucher specimens were deposited at the Museu de Zoologia "Prof. Adão José Cardoso" (ZUEC), Universidade Estadual de Campinas (Unicamp), according to the ICMBio (\#58836-1) permit, SISGen (\#A8A7729) protocol, and ethics committee (\#4827-1/2018) approval. 

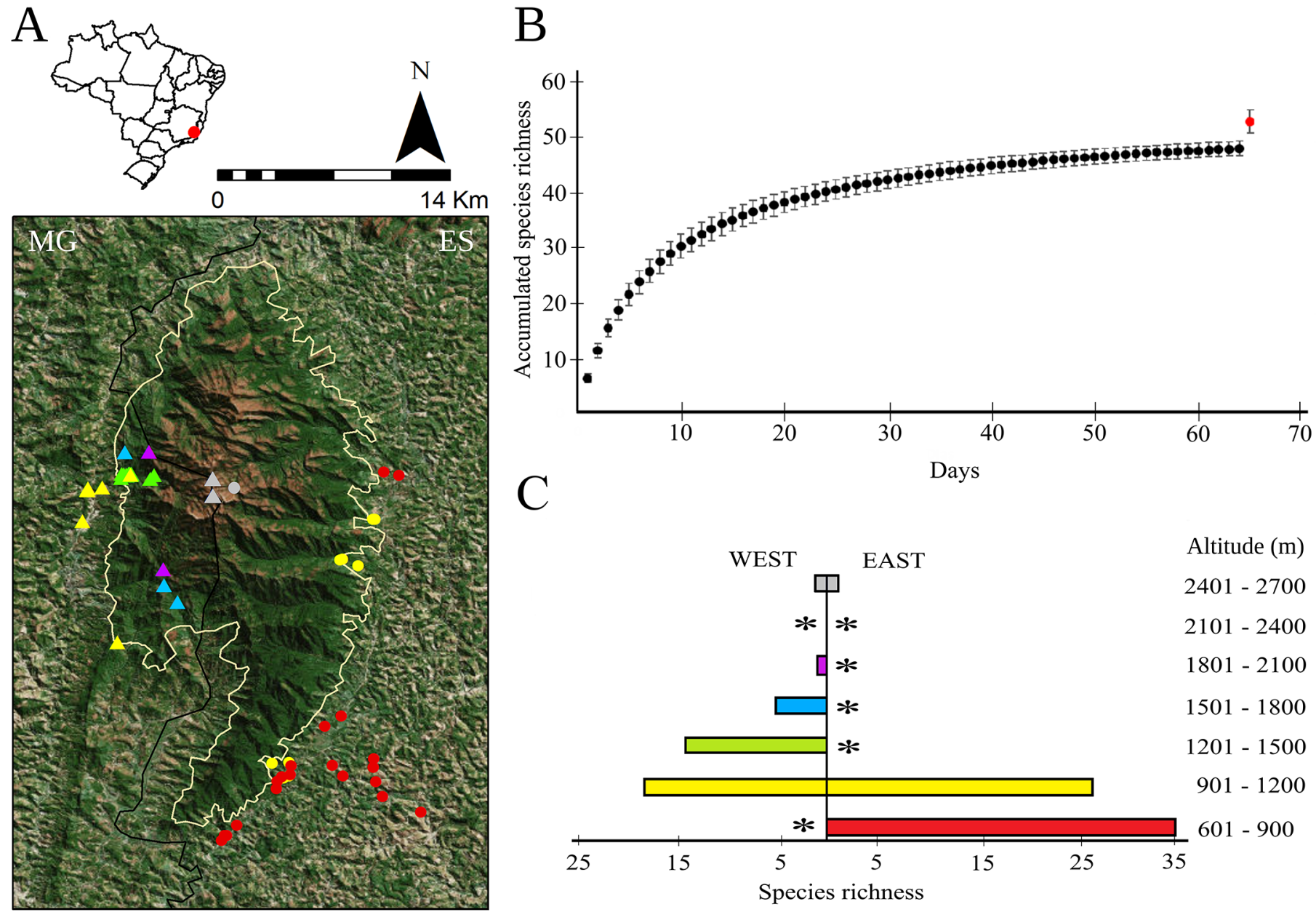

Figure 1. (A) Distribution of anuran species in the Caparaó National Park (CNP): yellow line determines the limits of the CNP, triangles correspond to registers in the west slope, dots in the east slope, and colors correspond to altitudinal ranges; black line represents the boundaries between states of Minas Gerais (MG) and Espírito Santo (ES). (B) Accumulated species richness during 63 days of survey; red dot corresponds to the jackknife 1 estimator for species richness. (C) Number of species registered in each altitudinal range; asterisks indicate areas not sampled. Geographical coordinates of all sample units are in Table S1. Diversity index values (ACE, ICE, Chao 1, Chao 2. Jackknife 1, Jackknife 2, Bootstrap) are in Table S2.

Anuran calls were recorded using digital recorders (TASCAM DR40, Marantz PMD 661, Sony PCM-M10, Zoom H4n, and Zoom H4n Pro) and were deposited at the Fonoteca Neotropical Jacques Vielliard (FNJV), ZUEC, Universidade Estadual de Campinas (Unicamp). Based on these samples we estimated diversity indexes (ACE, ICE, Chao 1, Chao 2, Jackknife 1, Jackknife 2, and Bootstrap) and constructed a sample-based accumulation curve with 1,000 randomizations using the software EstimateS 9.1.0 (Colwell 2013). We decided to show only the Jackknife 1 index as it is the best fitting index and the most used diversity index in species list studies.

Additionally, we combined this dataset with data from previous surveys carried out from 2004 to 2008, and with data from specimens deposited in the following Brazilian scientific collections: Museu de Zoologia da Universidade de São Paulo (MZUSP), São Paulo, São Paulo; Centro de coleções taxonômicas, Universidade Federal de Minas Gerais (UFMG), Belo Horizonte, Minas Gerais; Coleção Célio F. B. Haddad (CFBH), Universidade Estadual Paulista "Júlio de Mesquita
Filho", Rio Claro, São Paulo; Museu Nacional (MNRJ), Rio de Janeiro, Rio de Janeiro; and sound recordings from the Fonoteca Neotropical Jacques Vielliard (FNJV), ZUEC, Universidade Estadual de Campinas, Campinas, São Paulo.

Taxonomic nomenclature follows Frost (2020). Species identification was done by comparisons with previously collected individuals in scientific collections (Appendix I), species descriptions, sound recordings from individuals and additional DNA analyses for the ones we needed extra identification (e.g., tadpoles, juveniles or species complexes). For the molecular analyses we extracted total DNA and amplified a fragment of $16 \mathrm{~S}$ ribosomal DNA, following methods in Lyra et al. (2017). Purified fragments were sent to Macrogen, Republic of Korea for sequencing. We then used the blast tool (BLAST+ application, Camacho et al. 2009) to assign individuals to species. We assigned a species identification if similarity between sequences was higher than $98 \%$. The newly generated sequences were submitted to GenBank (accession numbers: MN450227-MN450262). 

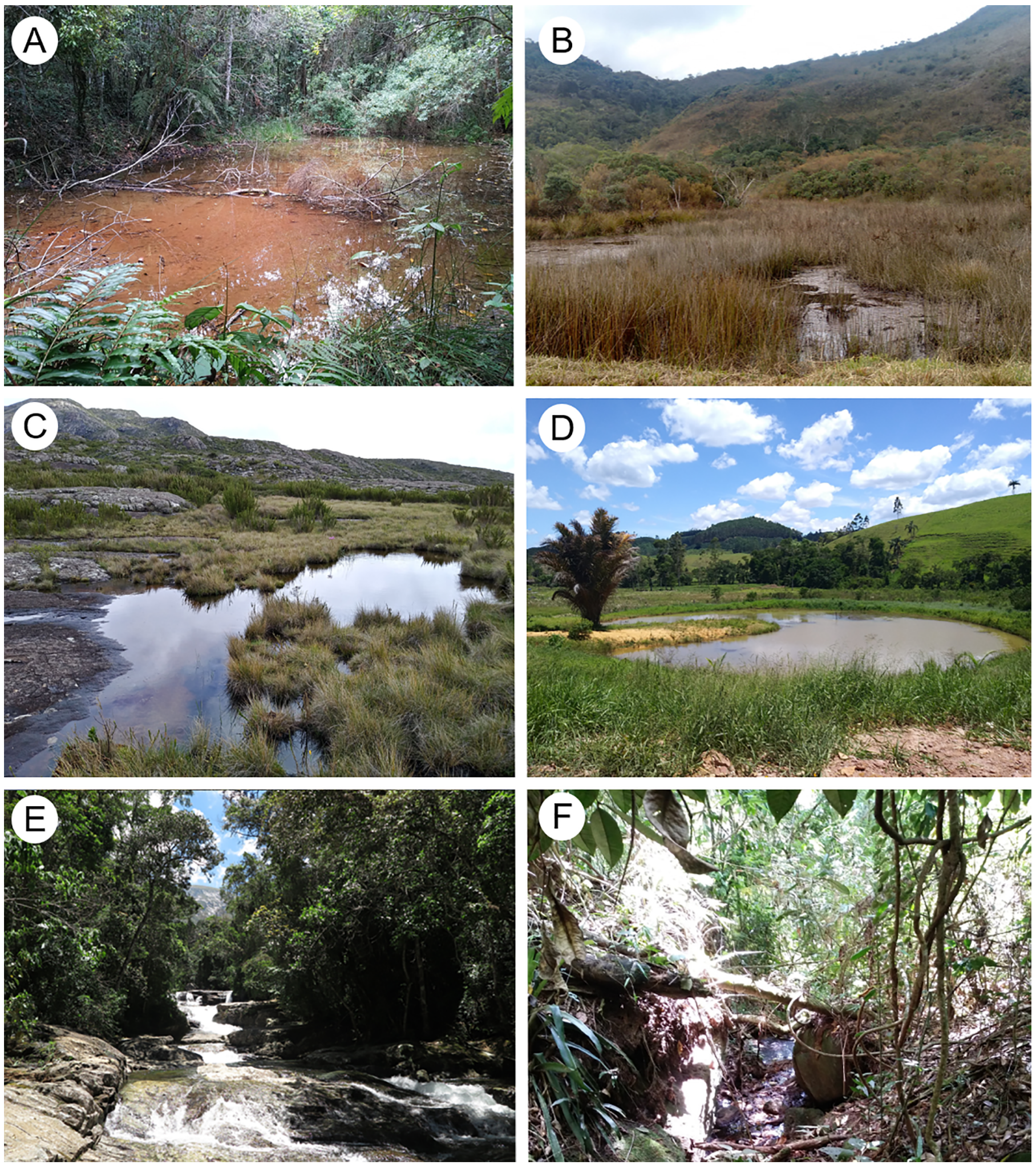

Figure 2. Anuran breeding sites at the Caparaó National Park (CNP) and surrounding areas. (A) swamp in forest areas, (B) swamp in open areas, (C) altitude lagoons, (D) artificial lagoons, (E) rivers and streams, (F) deciduous forest.

\section{Results}

We registered 47 species of anurans, from 11 families: Brachycephalidae (7 spp.), Bufonidae (2 spp.), Centrolenidae (2 spp.), Craugastoridae (1 sp.), Cycloramphidae (2 spp.), Hylidae (18 spp.),
Hylodidae (1 sp.), Leptodactylidae (9 spp.), Microhylidae (2 spp.), Odontophrynidae (1 sp.), and Phyllomedusidae (2 spp.). Two of the species are endemic for the CNP [Cycloramphus bandeirensis and Physalaemus sp. (aff. maculiventris)] and at least six of those species 
[Aplastodiscus sp. (possible Aplastodiscus sp. 6 of Berneck et al. 2016), Physalaemus sp. (aff. maculiventris), Ischnocnema spp. (three species), and Brachycephalus sp.] have not been described yet. From these not described species, Physalaemus sp. (aff. maculiventris) is abundant in the mountaintop but has extremely restricted distribution. On the other hand, the other five species [Aplastodiscus sp., Brachycephalus sp., and Ischnocnema spp. (three species)] are less abundant and were registered in forested microhabitats.

Gathering with the information from our previous surveys and secondary data from scientific collections, we compiled a list of 61 anuran species comprised in 12 families (Table 1; Figure 3-8; Appendix I), placing the Caparaó National Park (CPN) among the 10 amphibian richest sites in the AF (Table 2). The Jackknife 1 index estimated that we registered $93 \%$ of the species during the most recent two years of fieldwork (Figure 1B; Table S2).
However, these species corresponded to about $75 \%$ of the total species richness we were able to list. Species richness differed between both East and West slopes and among altitudinal ranges (Figure 1A, C). The site with the highest species richness was located in the East side from 600 to $900 \mathrm{~m}$, where we registered 34 species (Figure 1C). Although higher altitudes have less species, it is where the endemic ones were found, Cycloramphus bandeirensis and Physalaemus sp. (aff. maculiventris).

Two species present in scientific collections (Hylodes vanzolinii and Thoropa lutzi) were not sampled in the study area in recent times, even after directed efforts in their specific microhabitats. As an example, $H$. vanzolinii is known only by the holotype and one paratype, both collected in 1980 (Heyer 1982), and T. lutzi, which was collected in the CNP only in November 1980 and has never been registered again.

Table 1. Anuran species list from the Caparaó National Park (CNP) and surrounding areas. An asterisk * represents species that has the CNP as type locality; a hashtag \# indicates an undescribed species; a cross $\uparrow$ indicates a species that is not collected since the 1980s in the CNP. Slopes are west (W) and east (E). Data is classified as secondary (S), collected/primary (C), sound recorded (R) and identification confirmed by molecular analyses (M). Sample sites: Table S1.

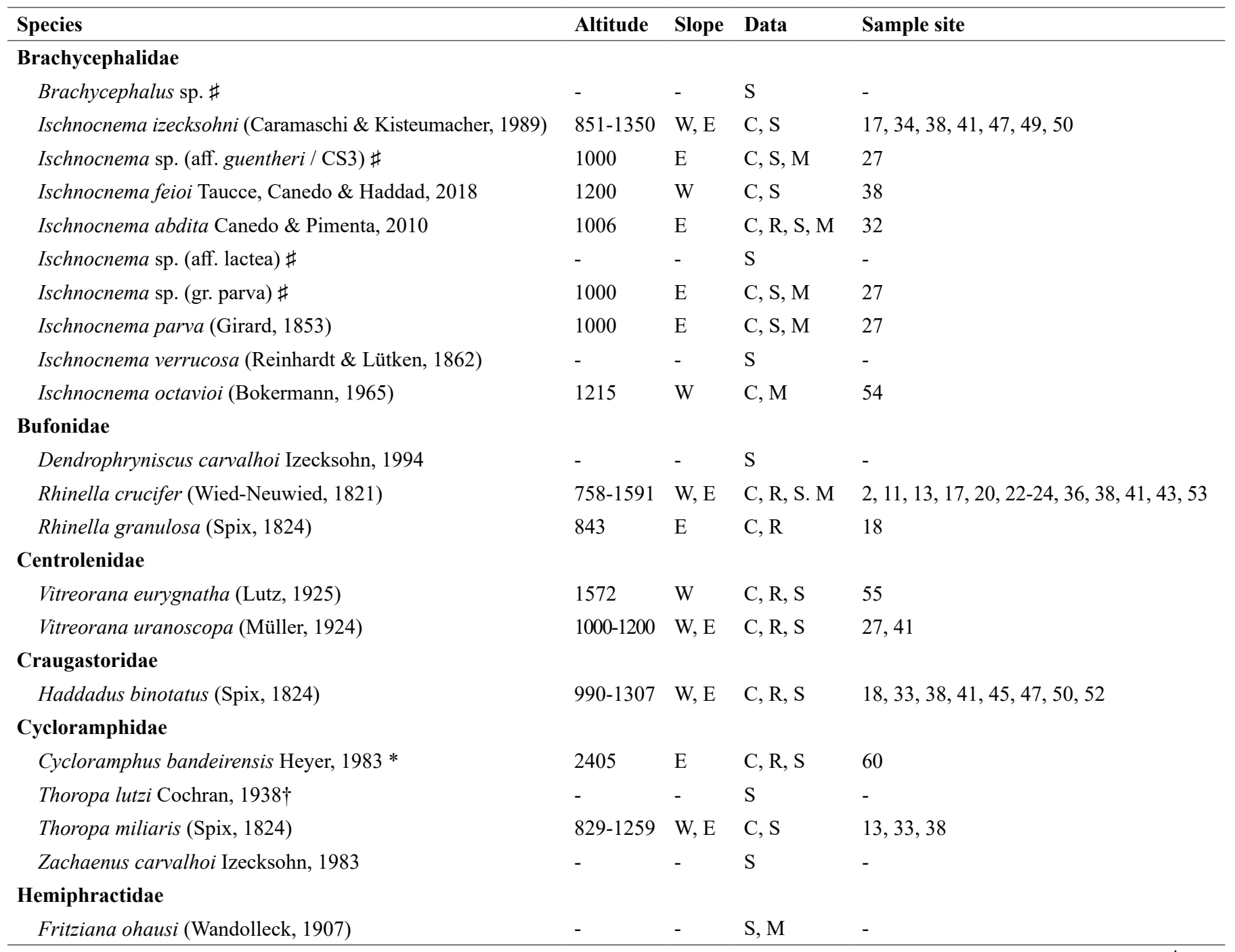




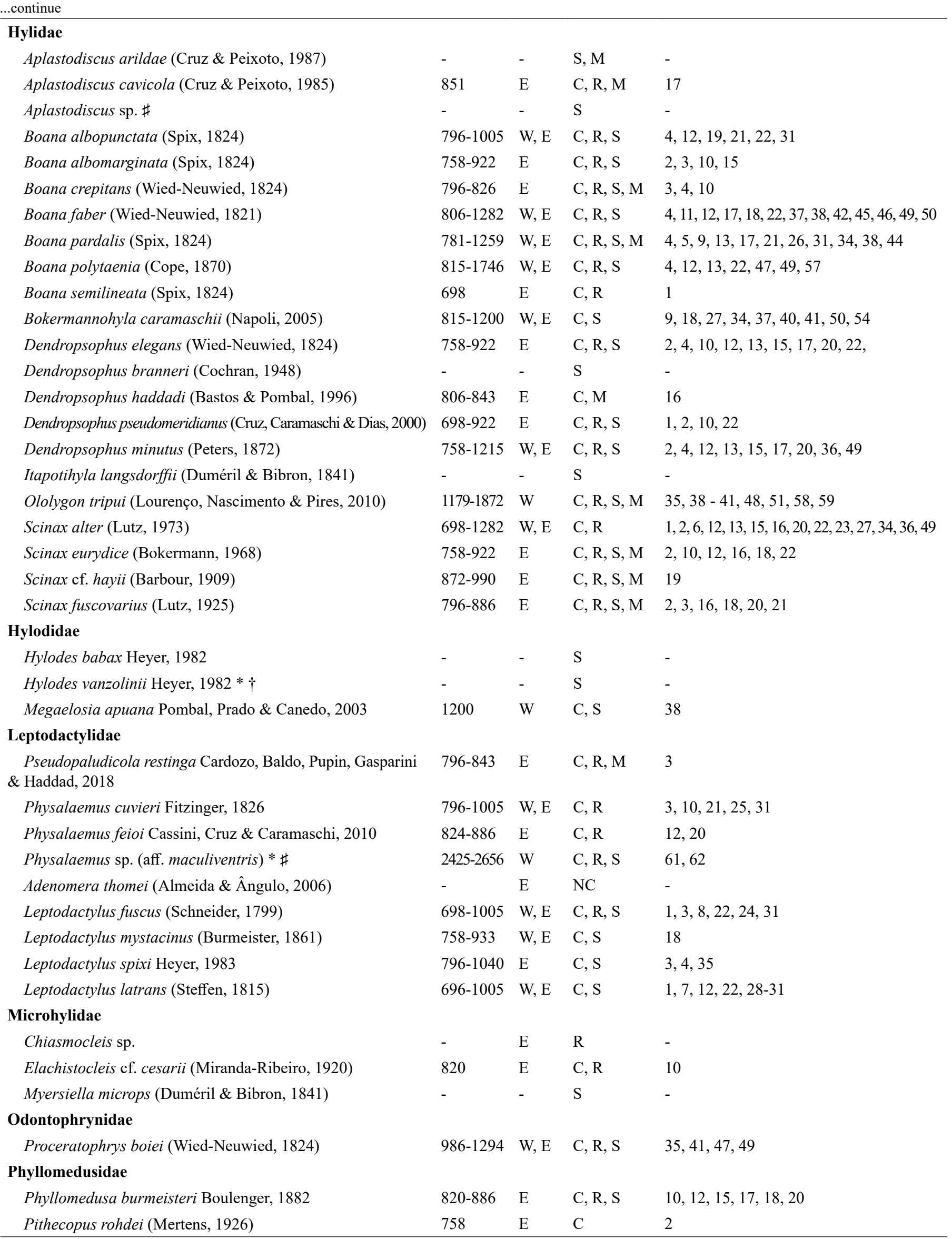



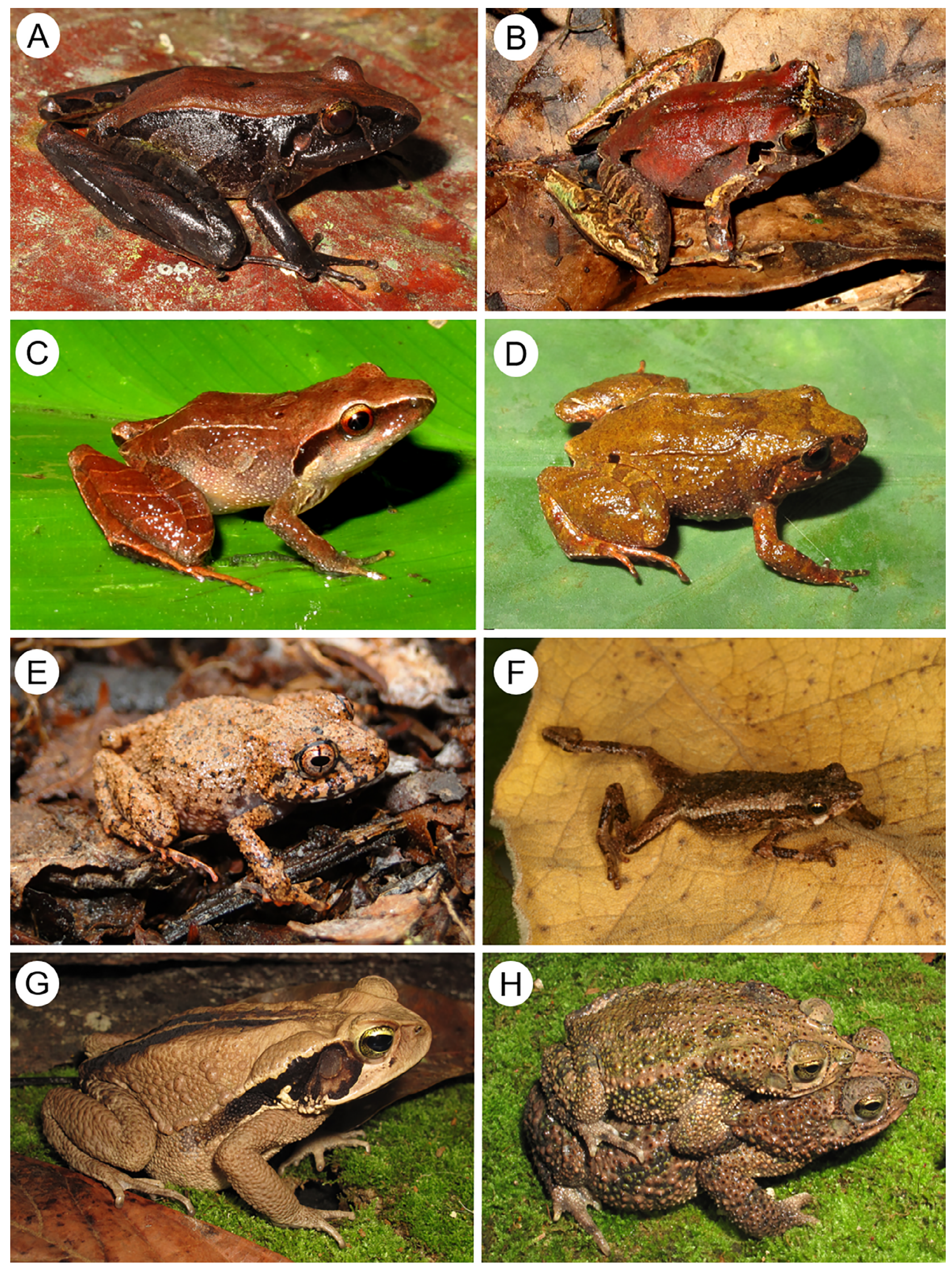

Figure 3. Anuran species found in the Caparaó National Park (CNP) and surrounding areas (SVL, snout-vent length, in millimeters). (A) Ischnocnema izecksohni (ZUEC 24371, SVL = 28.1); (B) I. feioi (not vouchered); (C) Ischnocnema sp. (gr. parva) (ZUEC 24365, SVL = 17.2); (D) I. parva (ZUEC 24352, SVL = 17.9); (E) I. verrucosa (UFMG 17230); (F) Dendrophryniscus carvalhoi (not vouchered); (G) Rhinella crucifer (not vouchered); (H) $R$. granulosa (ZUEC 23631, SVL = 50.3; ZUEC 23632, $\mathrm{SVL}=62.2$ ). 

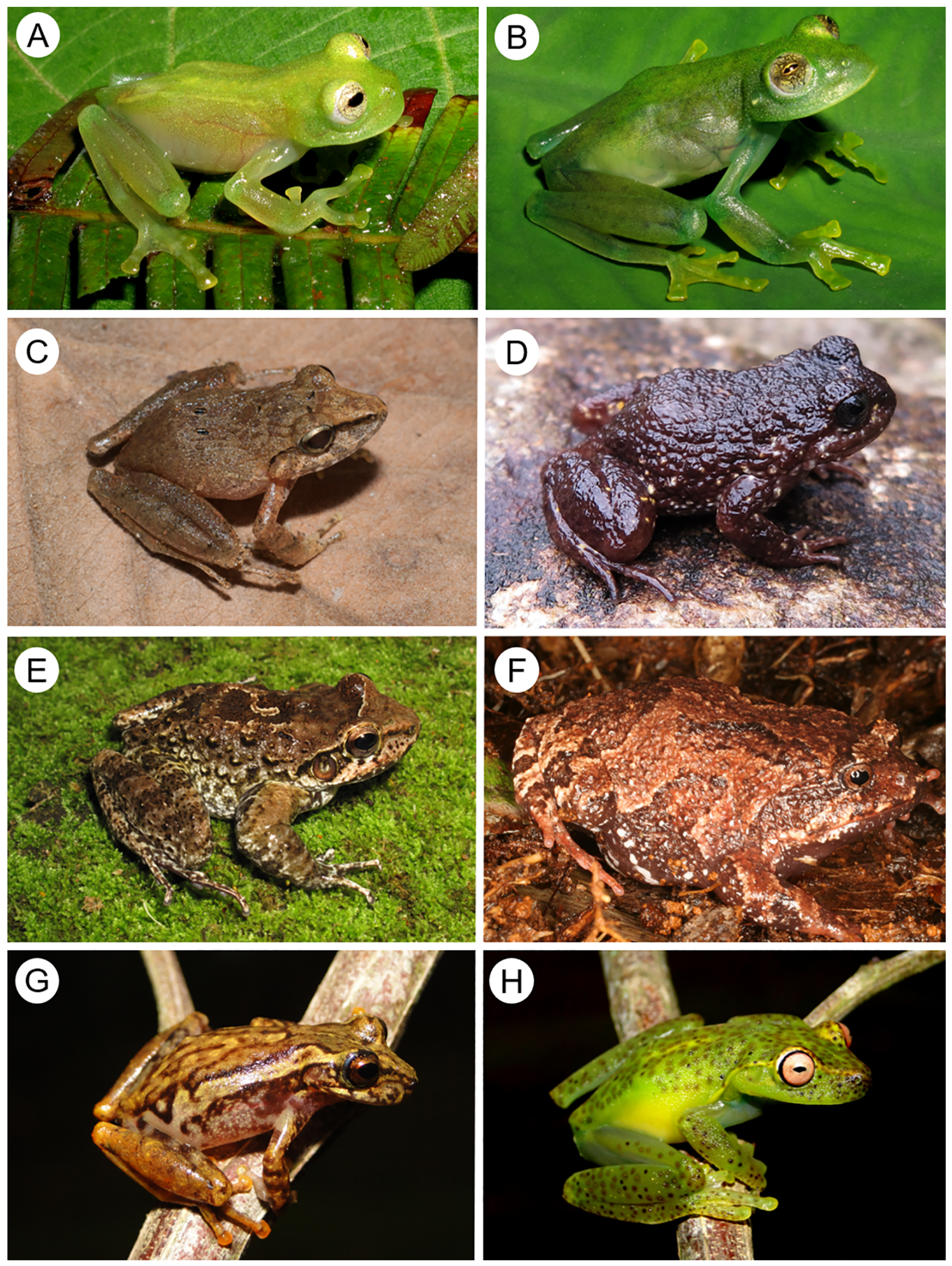

Figure 4. Anuran species found in the Caparaó National Park (CNP) and surrounding areas (SVL, snout-vent length, in millimeters). (A) Vitreorana eurygnatha (ZUEC 24380, SVL = 16.8); (B) V. uranoscopa (ZUEC 24376, SVL = 25.2); (C) Haddadus binotatus (not vouchered); (D) Cycloramphus bandeirensis (not vouchered); (E) Thoropa miliaris (not vouchered); (F) Zachaenus carvalhoi (not vouchered); (G) Fritziana ohausi (UFMG 17263); (H) Aplastodiscus arildae (UFMG 17259). Photograph C by Victor Fávaro Augusto. 

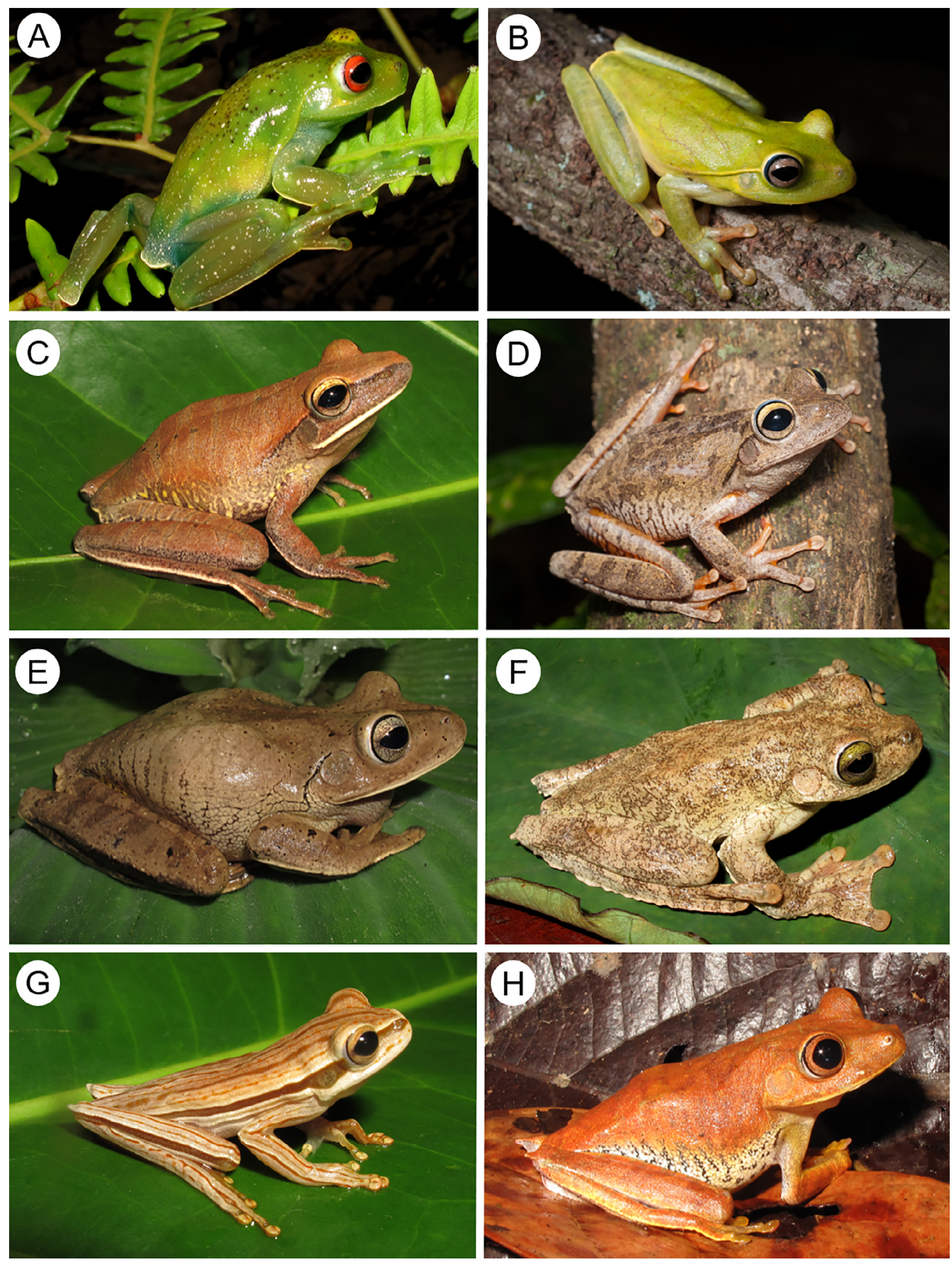

Figure 5. Anuran species found in the Caparaó National Park (CNP) and surrounding areas (SVL, snout-vent length, in millimeters). (A) Aplastodiscus cavicola (ZUEC 24368, SVL = 32.0); (B) Boana albomarginata (not vouchered); (C) B. albopunctata (ZUEC 23597, SVL = 48.5); (D) B. crepitans (ZUEC 24578, SVL = 55.1); (E) B. faber (ZUEC 23582, SVL = 77.9); (F) B. pardalis (not vouchered); (G) B. polytaenia (ZUEC 23617, SVL =26.4); (H) B. semilineata (ZUEC 24364, SVL = 43.0). Photograph B, C, and D by Victor Fávaro Augusto. 

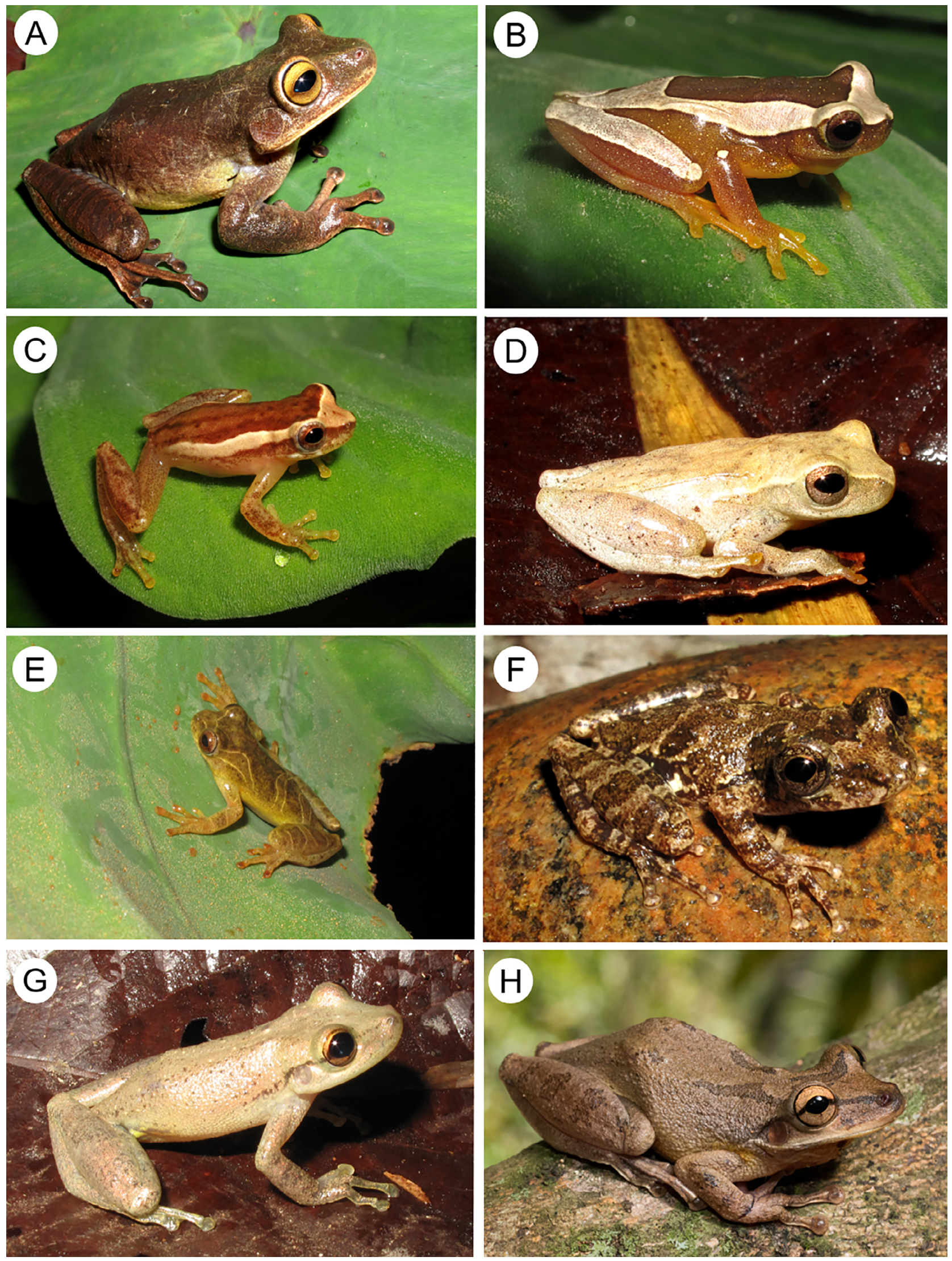

Figure 6. Anuran species found in the Caparaó National Park (CNP) and surrounding areas (SVL, snout-vent length, in millimeters). (A) Bokermannohyla caramaschii (ZUEC 24351, SVL=64.4); (B) Dendropsophus elegans (ZUEC 23616, SVL=25.7); (C) D. haddadi (ZUEC 23629, SVL =17.3); (D) D. pseudomeridianus (not vouchered); (E) D. minutus (not vouchered); (F) Ololygon tripui (ZUEC 23628, SVL=28.4); (G) Scinax alter (not vouchered); (H) S. eurydice (not vouchered). Photograph H by Victor Fávaro Augusto. 

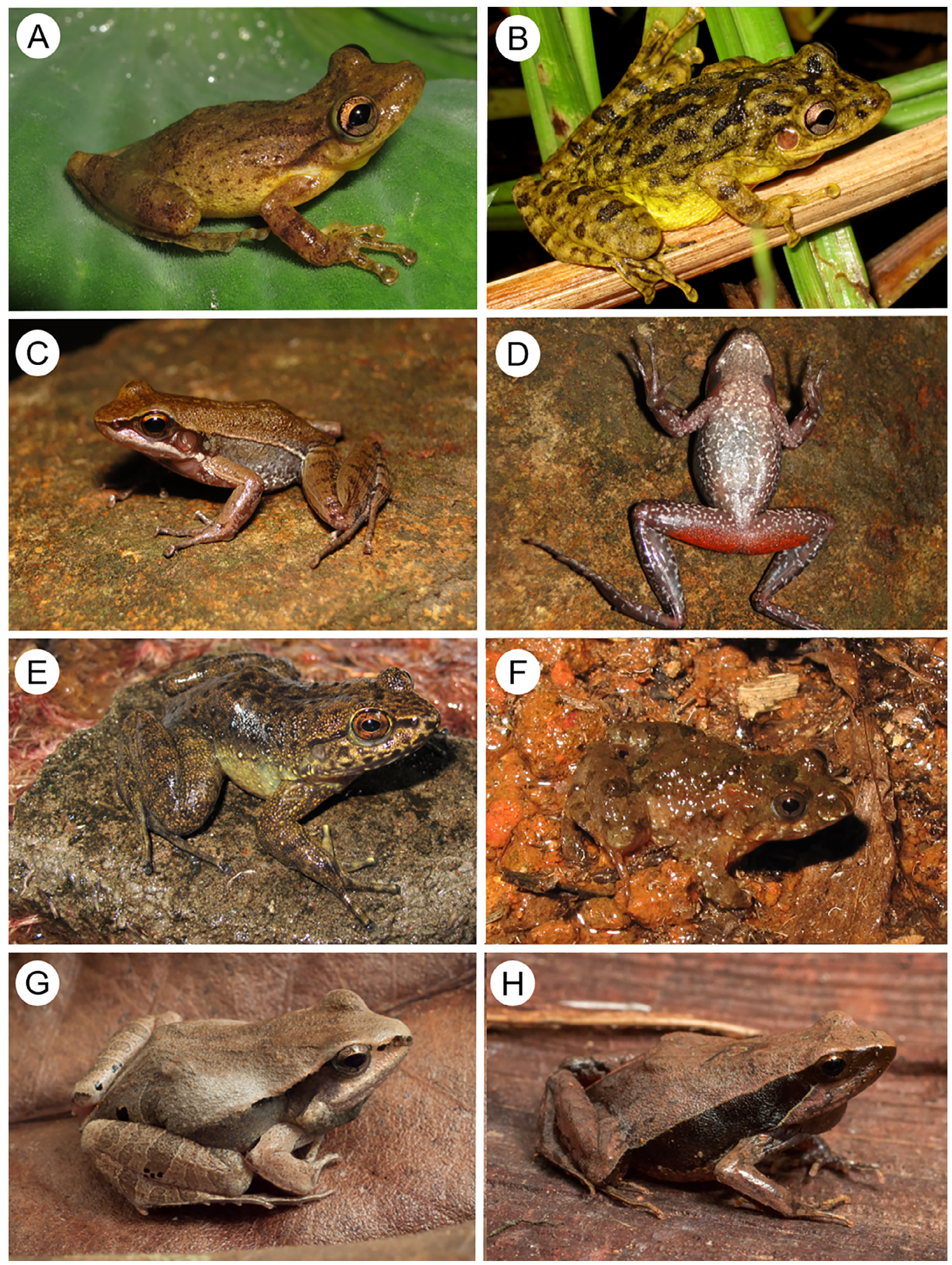

Figure 7. Anuran species found in the Caparaó National Park (CNP) and surrounding areas (SVL, snout-vent length, in millimeters). (A) Scinax cf. hayii (ZUEC 23598, SVL = 34.4); (B) S. fuscovarius (not vouchered); (C) Hylodes babax (UFMG 17258); (D) H. babax ventral view (UFMG 17258); (E) Megaelosia apuana (ZUEC 23497); (F) Pseudopaludicola restinga (not vouchered); (G) Physalaemus cuvieri (ZUEC 24566, SVL = 28.7); (H) P. feioi (ZUEC 24557, SVL = 20.3). Photographs G and H by Victor Fávaro Augusto. 

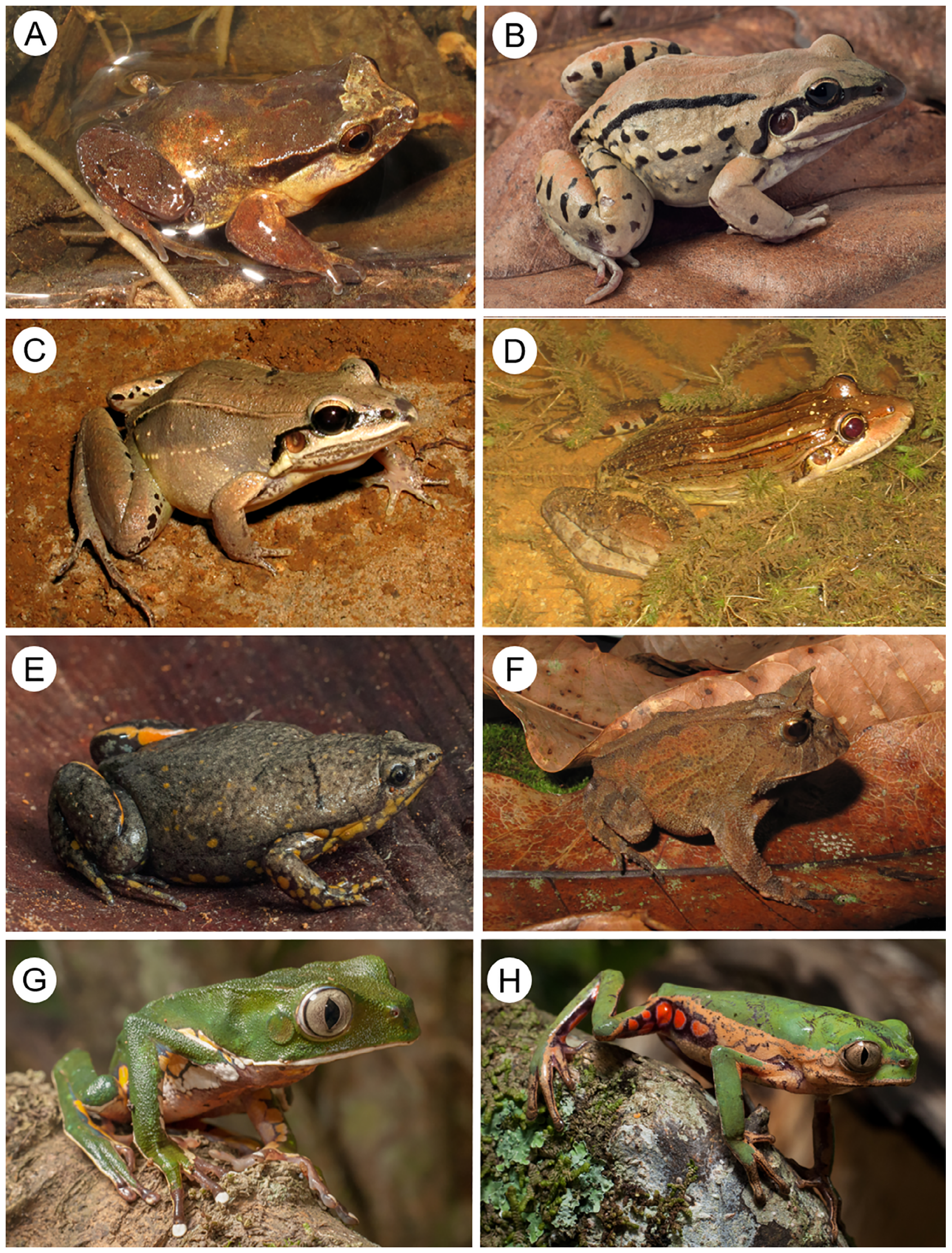

Figure 8. Anuran species found in the Caparaó National Park (CNP) and surrounding areas (SVL, snout-vent length, in millimeters). (A) Physalaemus sp. (aff. maculiventris) (not vouchered); (B) Leptodactylus mystacinus (ZUEC 24573, SVL = 53.1); (C) L. spixi (ZUEC 23627, SVL = 43.9); (D) L. latrans (not vouchered); (E) Elachistocleis cf. cesarii (ZUEC 24579, SVL = 30.5); (F) Proceratophrys boiei (ZUEC 23621, SVL = 51.2); (G) Phyllomedusa burmeisteri (not vouchered); (H) Pithecopus rohdei (ZUEC 24570, SVL = 37.4). Photographs B, E, G and H by Victor Fávaro Augusto. 
Table 2. Amphibian most rich localities in the Atlantic Forest. Time sampled ( $\dagger$ ) in a site refers to time reported in the literature and does not include historical samplings that can be retrieved in museum records. One asterisk $(*)$ refer that values were rounded to integer numbers. Two asterisks $(* *)$ symbolize that the area used was the area of the Tijuca National Park. Three asterisks (***) refer to an area unable to calculate. Brazilian states: (BA) Bahia, (ES) Espírito Santo, (MG) Minas Gerais, (RJ) Rio de Janeiro, (SP) São Paulo. RPPN, Reserva Particular do Patrimônio Natural (Private Reserve of Narutal Heritage).

\begin{tabular}{|c|c|c|c|c|c|}
\hline Locality & Species richness & Time sampled $\dagger$ & $\operatorname{Area}\left(\mathbf{k m}^{2}\right)^{*}$ & Species richness $/ \mathbf{k m}^{2}$ & Reference \\
\hline Municipality of Santa Teresa (ES) & 108 & $\approx 10$ years & 683 & 0.16 & $\begin{array}{l}\text { Ferreira et al. } \\
\text { (2019); Moura } \\
\text { et al. (2012) }\end{array}$ \\
\hline RPPN Serra Bonita (BA) & 80 & 88 days & 20 & 4.00 & Dias et al. (2014) \\
\hline Reserva Ecológica de Guapiaçu (RJ) & 73 & $\approx 7$ years & 13 & 5.62 & $\begin{array}{l}\text { Almeida-Gomes } \\
\text { et al. (2014) }\end{array}$ \\
\hline Estação Biológica da Boracéia (SP) & 67 & $\approx 5$ years & 165 & 0.41 & Heyer et al. (1990) \\
\hline $\begin{array}{c}\text { Parque Estadual da Serra do Mar - Núcleos } \\
\text { Curucutu, Santa Virgínia and São Sebastião (SP) }\end{array}$ & 65 & 81 days & 558 & 0.12 & Silva et al. (2017) \\
\hline Parque Estadual Carlos Botelho (SP) & 65 & 76 days & 378 & 0.17 & Forlani et al. (2010) \\
\hline
\end{tabular}

\section{Discussion}

This is a first comprehensive list of anurans for the Caparaó National Park (CNP) and surroundings. This update adds 40 anuran species to the list used for the park management plan (21 species) and place the CNP among the 10 amphibian richest sites in the Atlantic Forest (Table 2). Considering the size of the CNP and the other areas in the $\mathrm{AF}$, the CNP is the $4^{\text {th }}$ richest site, even we did not have access to all the areas of the park. Many of the species that were registered outside the limits of the CNP may also occur inside its boundaries. The CNP shares 40 species with the municipality of Santa Teresa (Ferreira et al. 2019) and 33 species with the Serra do Brigadeiro State Park (SBST) (Moura et al. 2012). The shared species are mainly abundant and widely distributed species, such as Rhinella crucifer, Boana albomarginata, B. albopunctata, B. faber, B. pardalis, B. polytaenia, B. semilineata, and Dendropsophus minutus. Resemblance in their amphibian species composition could be due the similar biogeographic origins, as these three localities belongs to the northern sector of the Mantiqueira mountain range (Gontijo-Pascutti et al. 2012), and also could be due to the proximity (140 km and $74 \mathrm{~km}$ straight-line distance, respectively), environmental and elevational similarities (Moura et al. 2012, Ferreira et al. 2019). Additionally, rare species, such as Hylodes babax, has been rediscovered in the past 10 years outside the CNP boundaries at Serra do Brigadeiro State Park and at Uaimií State Forest, both in the state of Minas Gerais, near the type locality (CNP) where the last record was in 2008 with a single specimen (Pirani et al. 2010, Verdade et. al. 2011).

The two endemic species found in this area are restricted to high-altitude grasslands (above 2,000 m). Physalaemus sp. (aff. maculiventris) is an abundant species with restricted distribution to altitude lagoons inside the CNP (Lagoa da sombra and Três lagoas) and has explosive reproduction. Cycloramphus bandeirensis can be found in high-altitude habitats at CNP and has a characteristic semiterrestrial reproductive mode (Verdade et al. 2019). High-altitude grasslands in the CNP undergo extreme temperature oscillations that could impact local amphibian populations (Veríssimo et al. 2012).
For example, the minimum temperature recorded in July 2017 was $-14{ }^{\circ} \mathrm{C}$ (Oliveira 2017) and there are recent reports of fires in CNP (G1 Minas 2019), which leads to local high temperatures and habitat loss, as observed in other high-altitude localities (Aximoff 2011). The undescribed species Ischnocnema spp. (three species), Brachycephalus sp. and Aplastodiscus sp. are less abundant, and although they inhabit decidual forests, a common environment in this area, we do not have specific information of their distribution range.

The lack of records of Hylodes vanzolinii and Thoropa lutzi in the Caparaó National Park could be related with local population declines or extinctions (see Verdade et al. 2011 for review of potential factors leading to amphibian declines in Brazil). If that is the case, a plausible cause would be the chytrid fungus, which spiked in the AF during the 1980's and was related to several amphibian extinctions in that decade (see Carvalho et al. 2017). We therefore indicate the need of higher sampling efforts and specific searches for those species. Furthermore, as this area has some species that were not described yet, it is even possible that some other not described species have vanished before our knowledge of their existence.

The publication of species lists is mandatory for the understanding of the regional biodiversity and is the basis for local wildlife conservation efforts. In this case, the current survey highlights one of the most amphibian diverse regions in the Atlantic Forest and reveals several species that should be described in the following years.

\section{Supplementary Material}

The following online material is available for this article:

Appendix I - Specimens or sound recordings examined and vouchered.

Table S1 - Sample sites/units (SUs) used in the anuran survey from Caparaó National Park and surrounding areas.

Table S2 - Diversity index values estimated for the amphibian assemblage of the Caparaó National Park. 


\section{Acknowledgments}

We thank C. Lambertini, L. Tacioli, C. Nunes-de-Almeida, R. Santos, M. Pontes, S. Dena, V. Augusto, M. Freitas, B. Dias, L. Ribeiro, A. Bertolazzi, D. Pavan, F. F. Curcio, L. D. Matos, M. Texeira Jr., and R. S. Recoder for helping during fieldwork; all residents of the surroundings of the CNP which allowed our research in their properties; Caparaó National Park for logistic support during research; CZ-T, GA-A, LFT, CFBH, MTR, VKV, PCAG, and JLG are grateful to the São Paulo Research Foundation (FAPESP \#2001/05470-8, \#2003/10335-8, \#2011/50146-6, \#2013/50741-7, \#2014/23388-7, $\# 2016 / 25358-3$, and \#2019/03170-0), the National Council for Scientific and Technological Development (CNPq \#300896/2016-6, \#140874/2019-4, \#306623/2018-8, and \#310301/2018-1), and the Brazilian Federal Agency for Support and Evaluation of Graduate Education (CAPES \#001). We also thank Biota Neotropica editors Marcelo Felgueiras Napoli and Carlos Joly for the constructive feedback and revisions on our manuscript.

\section{Author Contributions}

Camila Zornosa-Torres: Substantial contribution in the concept and design of the study; Contribution to data collection; Contribution to data analysis and interpretation; Contribution to manuscript preparation; Contribution to critical revision, adding intellectual content.

Guilherme Augusto-Alves: Contribution to data collection; Contribution to manuscript preparation; Contribution to critical revision, adding intellectual content.

Mariana L. Lyra: Contribution to data analysis and interpretation; Contribution to critical revision, adding intellectual content.

José Cassimiro da Silva Júnior: Contribution to data collection.

Paulo C.A. Garcia: Contribution to data collection.

Felipe Leite: Contribution to data collection.

Vanessa Verdade: Contribution to data collection; Contribution to critical revision, adding intellectual content.

Miguel T. Rodrigues: Contribution to data collection; Contribution to critical revision, adding intellectual content.

João Luiz Gasparini: Contribution to data collection; Contribution to critical revision, adding intellectual content.

Célio F. B. Haddad: Contribution to data collection; Contribution to critical revision, adding intellectual content.

Luís Felipe Toledo: Substantial contribution in the concept and design of the study; Contribution to data collection; Contribution to data analysis and interpretation; Contribution to manuscript preparation; Contribution to critical revision, adding intellectual content.

\section{Conflicts of Interest}

The authors declare that they have no conflict of interest related to the publication of this manuscript.

\section{Ethics}

Ethics committee approval \#4827-1/2018 stated in the Material and Methods section.

\section{References}

ALMEIDA-GOMES, M., SIQUEIRA, C.C., BORGES-JUNIOR, V.N.T., VRCIBRADIC, D., FUSINATTO, L.A. \& ROCHA, C.F.D. 2014. Herpetofauna of the Reserva Ecológica de Guapiaçu (REGUA) and its surrounding areas, in the state of Rio de Janeiro, Brazil. Biota Neotrop. 14(3):1-15. http://dx.doi.org/10.1590/1676-0603007813 (last access on 20/08/2019).

ARAUJO, C.O., CONDEZ, T.H., BOVO, R.P., CENTENO, F.C. \& LUIZ, A. M. 2010. Amphibians and reptiles of the Parque Estadual Turístico do Alto Ribeira (PETAR), SP: an Atlantic Forest remnant of Southeastern Brazil. Biota Neotrop. 10(4):257-274 http://www.biotaneotropica.org.br/v10n4/pt/ fullpaper?bn01710042010+en (last access on 20/08/2019).

AXIMOFF, I. 2011. O que perdemos com a passagem do fogo pelos campos de altitude do estado do Rio de Janeiro? Bio Brasil. 1(2):180-200.

BERNECK, B.V.M., HADDAD, C.F.B., LYRA, M.L., CRUZ, C.A.G., FAIVOVICH, J. 2016. The green clade grows: a phylogenetic analysis of Aplastodiscus (Anura; Hylidae). Mol. Phylogenet. Evol. 97:213-223.

CAMACHO, C., COULOURIS, G., AVAGYAN, V., MA, N., PAPADOPOULOS, J., BEALER, K. \& MADDEN, T.L. 2009. BLAST +: architecture and applications. BMC Bioinformatics. 10:421-429.

CARVALHO, T., BECKER, C.G. \& TOLEDO, L.F. 2017. Historical amphibian declines and extinctions in Brazil linked to chytridiomycosis. P R Soc B. 284:20162254.

COLWELL, R.K. 2013. EstimateS, Version 9.1: statistical estimation of species richness and shared species from samples (Software and User's Guide). http://viceroy.eeb.uconn.edu/estimates/EstimateSPages/EstSUsersGuide EstimateSUsersGuide.htm (last access on 20/08/2019).

DIAS, I.R., MEDEIROS, T.T., NOVA, M.F.V. \& SOLÉ, M. 2014. Amphibians of Serra Bonita, southern Bahia: a new hotpoint within Brazil's Atlantic Forest hotspot. Zookeys 449:105-130.

FERREIRA, L.M., LOPES, W.P., BEZERRA, E.F., CATHERINGER, L., MONTEIRO, A.L.M. \& RODRIGUES, T.D. 2015. Plano de Manejo Parque Nacional do Caparaó. Instituto Chico Mendes de Conservação da Biodiversidade, Brasilia. https://www.icmbio.gov.br/parnacaparao/ images/stories/PM_PNC--completo__PDF.pdf (last access on 20/08/2019).

FERREIRA, R.B., MÔNICO, A.T., DA SILVA, E.T., LIRIO, F.C.F., ZOCCA, C., MAGESKI, M.M., TONINI, J.F.R., BEARD, K.H., DUCA, C. \& SILVASOARES, T. 2019. Amphibians of Santa Teresa, Brazil: the hotspot further evaluated. ZooKeys 857:139-162.

FORLANI, M.C., BERNARDO, P.H., HADDAD, C.F.B. \& ZAHER, H. 2010. Herpetofauna do Parque Estadual Carlos Botelho, São Paulo, Brasil. Biota Neotrop.:265-309. https://doi.org/10.1590/S1676-06032010000300028 (last access on 20/08/2019).

FROST, D.R. 2020. Amphibian Species of the World: an Online Reference. Version 6.0. Available from: $\mathrm{http}$ ://research.amnh.org/herpetology/amphibia/ index.html (last access on 20/08/2019).

G1 MINAS. 2019. Incêndio atinge o Parque Nacional do Caparaó. Jornal G1. Available from: https:/g1.globo.com/mg/minas-gerais/noticia/2019/09/13/ parque-nacional-do-caparao-tem-incendio-de-grandes-proporcoes-dizadministracao.ghtml (last access on 28/01/2020).

GONTIJO-PASCUTTI, A.H.F., HASUI, Y., SANTOS, M., SOARES, A.V., \& SOUZA, I.A. 2012. As serras do Mar e da Mantiqueira. In Geologia do Brasil (Y. Hasui, C.D.R. Carneiro, F.F.M. Almeida, \& A. Bartorelli, eds). Beca, Brazil. p. 549-571.

GUARNIZO, C.E. \& CANNATELLA, D.C. 2013. Genetic divergence within frog species is greater in topographically more complex regions. J. Zool. Syst. Evol. Res. 51(4):333-340.

HADDAD, C.F.B., TOLEDO, L.F., LOEBMANN, C.P.A., GASPARINI, J.L. \& SAZIMA, I. 2013. Guia dos anfíbios da Mata Attântica - diversidade e biologia. Anolis Books, São Paulo.

HEYER, W.R. 1982. Two new species of the frog genus Hylodes from Caparaó, Minas Gerais, Brazil (Amphibia: Leptodactylidae). Proc. Biol. Soc. Wash. 95(2):377-385. 
HEYER, W.R. 1983. Variation and systematics of frogs of the genus Cycloramphus (Amphibia, Leptodactylidae). Arq. Zool. 30(4):235-339.

HEYER, W.R., RAND, A.S., CRUZ, C.A.G., PEIXOTO, O.L. \& NELSON, C.E. 1990. Frogs of Boracéia. Arq. Zool. 31(4):237-410.

LYRA, M.L., HADDAD, C.F.B. \& AZEREDO-ESPIN, A.M.L. 2017. Meeting the challenge of DNA barcoding Neotropical amphibians: polymerase chain reaction optimization and new COI primers. Mol. Ecol. Resour. 17(5):966-980

MACHADO, T.M., FORZZA, R.C. \& STEHMANN, J.R. 2016. Bromeliaceae from Caparaó National Park, Minas Gerais/Espírito Santo states, Brazil, with notes on distribution and conservation. Oecol Aust. 20(2):133-146.

MITTERMEIER, R.A., TURNER, W.R., LARSEN, F.W., BROOKS, T.M. \& GASCON, C. 2011. Global Biodiversity Conservation: The Critical Role of Hotspots. In Biodiversity Hotspots: Distribution and Protection of Consevation Priority Areas (F.E. Zachos \& J.C. Habel, eds). Springer, Berlin, p.3-22.

MORELLATO, L.P.C. \& HADDAD, C.F.B. 2000. Introduction: the Brazilian Atlantic Forest. Biotropica. 32(4b):786-792.

MOURA, M.R., MOTTA, A.P., FERNANDES, V.D. \& FEIO, R.N. 2012 Herpetofauna da Serra do Brigadeiro, um remanescente de Mata Atlântica em Minas Gerais, sudeste do Brasil. Biota Neotrop. 12(1):209-235. http:// dx.doi.org/10.1590/S1676-06032012000100017 (last access on 28/01/2020).

OLIVEIRA, N. 2017. Geada toma conta do Pico da Bandeira que registro $-14^{\circ} \mathrm{C}$. Jornal O Tempo. Available from: https://www.otempo.com.br/cidades/ geada-toma-conta-do-pico-da-bandeira-que-registrou-14-c-1.1493520 (last access on 28/01/2020).

PIRANI, R.M., MÁNGIA, S., SANTANA, D.J., ASSIS, B. \& FEIO, R.N 2010. Rediscovery, distribution extension and natural history notes of Hylodes babax (Anura, Hylodidae) with comments on southeastern Brazil biogeography. South Am. J. Herpetol. 5(2):83-88.

RIBEIRO, M.C., MARTENSEN, A.C., METZGER, J.P., TABARELLI, M., SCARANO, F. \& FORTIN, M.J. 2011. The Brazilian Atlantic Forest: A Shrinking Biodiversity Hotspot. In Biodiversity Hotspots: Distribution and Protection of Consevation Priority Areas (F.E. Zachos \& J.C. Habel, eds). Springer, Berlin, p. 405-434.

ROSSA-FERES, D., GAREY, M. V, CARAMASCHI, U., NAPOLI, M.F., NOMURA, F., BISPO, A.A., BRASILEIRO, C.A., THOMÉ, M.T.C., SAWAYA, R.J., CONTE, C.E., CRUZ, C.A.G., NASCIMENTO, L.B., GASPARINI, J.L., ALMEIDA, A.P. \& HADDAD, C.F.B. 2018. Anfíbios da Mata Atlântica: Lista de espécies, histórico dos estudos, biologia e conservação. In Revisões em zoologia, Mata Atlântica (E.L.A. MonteiroFilho \& C.E. Conte, eds). Editora UFPR, Curitiba, p. 237-314.
SILVA, F.R., LYRA, M.L., HADDAD, C.F.B. \& ROSSA-FERES, D.D.C. 2017. Expanding the knowledge about the occurrence of anurans in the highest amphibian diversity area of Atlantic Forest: Parque Estadual da Serra do Mar, São Paulo, Brazil. Biota Neotrop. 17(2):e20160282. http://dx.doi. org/10.1590/1676-0611-BN-2016-0282 (last access on 20/08/2019).

TOLEDO, L.F., BECKER, C.G., HADDAD, C.F.B. \& ZAMUDIO, K.R. 2014. Rarity as an indicator of endangerment in Neotropical frogs. Biol Conserv. 179:54-62.

VACINE, M.H., DUARTE, K.S., SOUSA, Y.S., GIOVANELLI, J.G.R., MARTINS-SOBRINHO, P.M., LÓPEZ, A., BOVO, R.P., MAFFEI, F., LION, M.B., JÚNIOR, J.W.R., BRASSALOTI, R., Da COSTA, C.O.R., SAWAKUCHI, H.O., FORTI, L.R., CACCIALI, P., BERTOLUCI, J., HADDAD, C.F.B. \& RIBEIRO, M. C. 2018. Atlantic amphibians: a data set of amphibian communities from the Atlantic Forest of South America. Ecology. 99(7):1692.

VASCONCELOS, T.S., PRADO, V.H.M., SILVA, F.R. \& HADDAD, C.F.B. 2014. Biogeographic distribution patterns and their correlates in the diverse frog Fauna of the Atlantic Forest Hotspot. PLoS ONE 9:e104130.

VERDADE, V.K., RODRIGUES, M.T. \& PAVAN, D. 2009. Anfíbios anuros da região da Estação Biológica do Alto da Serra de Paranapiacaba. In Patrimônio da Reserva Biológica de Alto da Serra de Paranapiacaba: a antiga Estação Biológica do Alto da Serra (M.I.M.S. Lopes, M. Kirizawa, \& M.M. da R.F. de Melo, eds). Secretaria do Meio Ambiente do Estado de São Paulo, São Paulo, p.579-604.

VERDADE, V.K., CARNAVAL, A.C., RODRIGUES, M.T., SCHIESARI, L. \& BERTOLUCI, J. 2011. Chapter 5: Decline of amphibians in Brazil. In Amphibian Biology (H. Heatwole, ed.), Volume 9 Status of decline of amphibians: Western Hemisphere (C.I. Barrio-Amorós and J.W. Wilkinson, co-eds), Part 2: Uruguay, Brazil, Ecuador and Colombia. Surrey Beatty and Sons, Australia, p.85-127.

VERDADE, V.K., ALMEIDA-SILVA, D., CASSIMIRO, J. \& RODRIGUES, M.T. 2019. Rediscovering Cycloramphus bandeirensis (Anura: Cycloramphidae): natural history and breeding biology of a vulnerable species with a variant reproductive mode. Phyllomedusa 18(2):159-175.

VERÍSSIMO, N.P., SAFFORD, H.F., BEHLING, H. 2012. Holocene vegetation and fire history of the Serra do Caparaó, SE Brazil. The Holocene 22(11):1243-1250. 